\title{
Is Banded Leaf and Sheath Blight a Potential Threat to Maize Cultivation in Bihar?
}

\author{
Dinesh Rai* and S.K. Singh \\ Department of Plant Pathology, Dr. Rajendra Prasad Central Agricultural University, Pusa, \\ Samastipur - 848125, Bihar, India \\ *Corresponding author
}

\begin{abstract}
A B S T R A C T
Maize is the $3^{\text {rd }}$ most important crop in the Bihar next to rice and wheat. It is grown throughout the year in one or other part of state. Due to continuous cropping of maize and other factors like improper use of fertilizers, pesticides and climate change, the disease problem has increased in tremendous proportion. Almost all parts of the maize plant are susceptible to numerous diseases that considerably reduce the yield and quality of the crop. Among the various diseases of maize, banded leaf and sheath blight caused by most widespread, destructive and versatile pathogen Rhizoctonia solani f. sp. sasakii has attained the status of economically important disease. The disease is difficult to control through either fungicides or crop rotation alone due to its soil borne nature and unavailability of resistance source. This disease causes direct loss due to premature death of early infected plants and stalk breakage and ear rot in the older plants. Losses in grain yield to the extent of 11 to 40 per cent under favourable conditions have been reported due to banded leaf and sheath blight. In Bihar this disease has been occurring in severe form in some maize growing districts and causing substantial losses in term of yield. The increasing of severity of this disease may be due to continuous growing of hybrids and favourable climate change for its pathogen growth and suitability. The consolidated knowledge presented in this review should help better understanding of the threat of banded leaf and sheath blight to maize cultivation in Bihar.
\end{abstract}

\section{Introduction}

Maize is an important cereal crop in the world. It has several important uses for industrial purposes, human food and animal feed. It is grown under variety of agroecological conditions and posses highest yield potential above 80 quintal per hectare among the food grain crop. India has to increase maize production in the country by 75 per cent to 45 million tonnes (mt) by 2022 to meet the increasing domestic requirement. By 2022, India would need $30 \mathrm{mt}$ of maize for feed and another $15 \mathrm{mt}$ for food (The Hindu, 2017). The predominant maize growing states that contributes more than $80 \%$ of the total maize production are Andhra Pradesh (20.9 \%), Karnataka (16.5\%), Rajasthan (9.9\%), Maharashtra (9.1\%), Bihar (8.9\%), Uttar Pradesh (6.1 \%), Madhya Pradesh (5.7 \%), Himachal Pradesh (4.4\%). Apart from these states maize is also grown in Jammu and 
Kashmir and North-Eastern states (Parihar et al., 2011).

In the state of Bihar maize has emerged as the major cash crop of the state, spread over most of the 38 districts. The maize production in the state during 2016-17 was 3.85 million tonnes with the productivity of 53.55 quintals per hectare (India Infoline, 2017). It is cultivated in almost all districts, all the seasons i.e. Kharif, Rabi, Summer and in all types of agro-ecological regions of Bihar, though 15 districts together contributed about 80 per cent of the total maize production in the state, which mainly fall in the agroclimatic zones I and II (Directorate of Economics Statistics, 2014). These districts are flood-prone areas during rainy season historically and fall north of the Ganges, having several seasonal river tributaries. Begusarai, Khagaria, Samastipur, Katihar and Madhepura are the leading maize-growing districts with more than 45 thousand ha area in each district and producing more than 100 thousand tonnes of maize grain every year. In some of the districts, marginal decrease in the maize area was observed in the recent past. In some districts like Katihar and Khagaria, area under this crop has significantly increased while in Muzaffarpur district it declined during the previous decade. Among the major maize-growing districts, 6 districts (Bhagalpur, Begusarai, East Champaran, Madhepura, Saran and Siwan) showed a declining trend in the yield, whereas 8 districts (Araria, West Champaran, Katihar, Khagaria, Purnia, Saharsa, Samastipur and Vaishali) depicted an increasing trend. There was not much change in the maize yield in most of the districts, except that in Araria and West Champaran in the state. Several factors have been reported for this up and down situation in maize cultivation.

Maize is prone to a number of foliar, ear rot and stalk rot diseases incited by fungi, bacteria and viruses. Under favourable environmental conditions a number of them are capable of causing severe losses and impair the quality of the produce or even complete failure of the crop. Almost all parts of the maize plant are susceptible to numerous diseases that considerably reduce the yield and quality of the crop. Due to continuous cultivation of maize and other factors like improper use of fertilizers, pesticides and climate change, the disease problem has increased in tremendous proportion (Gautam et al., 2013). Among the various diseases of maize, banded leaf and sheath blight caused by pathogen Rhizoctonia solani f. sp. sasakii has attained the status of economically important disease (Hooda, et al., 2015). Increased incidence of BLSB has been observed in different districts of Bihar under climate changing scenario. The pathogen spreads from the basal sheath to the developing ear under favorable environmental conditions. In the humid condition, disease severity increases and light brown, cottony mycelium with small, round and black sclerotia can be seen on the ear. The disease causes direct losses, resulting in premature death, stalk breakage and ear rot, indirect losses by not only reducing the grain yield but also in grain quality in terms of human consumption.

\section{Banded Leaf and Sheath Blight (BLSB)}

More than 112 diseases have been reported on maize from different parts of the world. Of these, 65 are known to occur in India. The major diseases in different agro climatic regions are: seed rots and seedling blight, leaf spots and blights, downy mildews, stalk rots, banded leaf and sheath blight, and smuts and rusts, leading to about 15-20 percent yield losses annually (Saxena, 2002). Among them Banded Leaf and Sheath Blight (BLSB) of maize caused by Rhizoctonia solani f. sp. sasakii Exner (teleomorph: Thanatephorus 
sasakii (Shirai) Tu \& Kimbro), is gaining economic importance. It was reported for the first time from Sri Lanka by Bertus in1927 under the name sclerotial disease (Bertus, 1927). In recent years, its outbreaks have occurred in a number of countries assuming epidemic dimensions (Sharma, 2002). In India, the Banded Leaf and Sheath Blight disease was first reported in 1960 from Tarai region of Uttar Pradesh. The causal organism was Hypochonus sasakii (Payak and Renfro, 1966) which appeared in epidemic form in 1972 in Mandi district of Himachal Pradesh (Thakur et al., 1973). The introduction of maize hybrids, the disease has become a major constraint for maize production in the state. Favourable conditions i.e. water lodged condition, temperature, humidity and present of high inoculums load in the field increasing the incidence and severity of this disease in different maize growing districts of Bihar. Since the pathogen is soil borne, the disease starts from first leaf sheath to upward and even up to the ears to cause maximum damage. In India it is known to be present in the states of Himachal Pradesh, Uttar Pradesh, Bihar, Haryana, Punjab, Madhya Pradesh, Rajasthan, West Bengal, Meghalaya, Assam, Nagaland, Andhra Pradesh and Orissa.

\section{Economic importance}

Different diseases occur during different seasons, if they are not managed at proper time than they leads to yield loss. Estimated losses due to major diseases of maize in India is about $13.2 \%$ of which foliar diseases (5\%), stalk rots, root rots, ear rots $(5 \%)$ cause major yield losses (Parihar et al., 2011). Among the various diseases, Banded leaf and sheath blight has been considered as one of the major disease of maize. The disease causes direct losses resulting in premature death, stalk breakage and ear rot indirect losses by reducing the grain yield. Earlier Singh and Sharma (1976) estimated 40.5 per cent losses in grain yield of comparable variety Vijay. Lal et al., (1980) have also estimated grain yield ranging from 23.9 to $31.9 \%$ in ten cultivars of maize. Payak and Sharma (1981) reported that annually around one per cent of the total grain yield is reduced by BLSB in India. Sharma et al., (2004) proved that banded leaf and sheath blight are major disease of maize and grain yield loss depends on disease severity which varies between 1140 per cent. Buddemeyer et al., (2004) observed $37 \%$ reduction in fresh dry matter and $12 \%$ reduction in grain yield due to $R$. solani AG-2-2IIIB in maize in sugar beetmaize cropping system. In USA, a yield reduction of $42 \%$ has been observed in infested plots with high inoculum level (Sumner and Minton, 1989). In Guangxi province of China, yield losses of 87.5 and $57.8 \%$ were recorded under natural conditions in the hybrids Luyu13 and Guiding planted at Bao Qiao and Chen Xiang (Sharma, 2005). Hooda et al., (2017) stated that banded leaf and sheath blight is the most destructive disease and it could cause an economic loss of up to $100 \%$. Due to the wide host range and the ability to survive as sclerotia under adverse environmental conditions of this disease become more destructive (Groth and Bond, 2006; Hooda et al., 2017).

\section{Symptoms}

Banded leaf and sheath blight appears at the pre-flowering stage in 40-50 day old plants but infection can also occur on younger plants in natural condition. In later case, severe blight occurs which is accompanied by death of the apical growing point. The diseases manifests itself on leaf, leaf sheath, stalks and ears as leaf and sheath blight, stalk lesions or rind spotting and stalk breakage, clumping and cracking of styles (silk fibers) and horseshoe shaped lesions with banding of caryopses resulting in ear rots (Ahujha and Payak, 1982; Sharma, 1999; Rani et al., 
2015). BLSB disease infection starts from the lowest leaf sheath or on leaves which are in contact with soil and spreads up to the ear under natural condition. Initially, the irregular, globular to elongated lesions appear as water soaked areas. These become bleached or straw coloured and necrotic.

The symptoms appeared on inoculated plants as irregular shaped spots. Typical banded leaf and sheath blight symptoms were observed as small purplish brown lesions or greenish olive brown large continuous patches on leaf sheath and pale olive brown lesions on stalk as well as rotting of ears (Akthar et al., 2009). The symptoms and morphological characters observed in the present investigations have also been recorded and described by several workers (Duggar, 1915; Reyes, 1941; Sohi et al., 1965; Singh and Sharma, 1976 and Maiti, 1978).

The pathogen (Rhizoctonia solani f. sp. sasakii (Khun.)

Banded leaf and sheath blight (BLSB) incited by $R$. solani f. sp. sasakii (Khun.) was first recorded on maize in Sri Lanka (Bertus, 1927). The genus Rhizoctonia was created in the year 1815 by DeCandolle (1915) for the non-sporulating root pathogen $R$. crocorum D.C. ex. Fr. Later, German scientist Julius Kuhn described it as Rhizoctonia solani isolated from diseased potato tubers. From India, Payak and Renfro (1966) were the first to report the occurrence of banded leaf and sheath blight disease of maize caused by $R$. solani f.sp sasakii (Khun.) [Thanatephorus cucumeris (Frank)] Donk from Tarai region of U.P. in 1960. High incidence of banded leaf and sheath blight of maize was observed in Jhadol and other hilly regions of Udaipur district of Rajasthan (AICMIP, 1966). BLSB disease caused by $R$. solani f. sp.sasakii = Hypochonus sasakii [Thanatephorus cucumeris (Frank) Donk] is one of the most widespread, destructive, and versatile pathogen prevalent in most parts of the world with a wide host range including maize causing seed decay, damping-off, stem canker, root rot, aerial blight, and seed or cob decay. $R$. solani f. sp. sasakii is morphologically characterized by pale to brown colour of mycelium, branching near the distal septum in young growing hyphae, presence of a constriction and formation of a septum in branch near the point of origin, absence of clamp connections, sclerotia of undifferentiated texture, young multinucleate hyphal cells with a prominent septal pore apparatus and rapid growth rate. The characteristics of hyphae of Rhizoctonia are a) branching near distal septum of cells in young vegetative hyphae; $b$ ) formation of septum in the branch near the point of origin, c); construction of branch; d) doliporeseptum; e) no clamp connection; f) no conidium; g) sclerotium not differentiated in rind and medulla and h) no rhizomorph (Ogoshi, 1975). The mature hyphae branch at right angle and sclerotia are produced abundantly in culture and on infected plant parts. Mostly, sclerotiaare 1 to $5 \mathrm{~mm}$ in diameter with spherical shape, and dark brown to black colour.

\section{Disease cycle}

The primary source of inoculum is sclerotia in the soil and grass hosts that grow in the vicinity of maize crop. Sclerotia can persist in the soil for several years. Sclerotia which survive on plant debris often come up on the soil surface during field preparation and other operations. They come in contact with newly planted seedlings/plants. At the onset of the growing season, in response to favourable humidity and the fungal growth is attracted to newly planted crops by chemical stimulants released by growing plant cells and cause infection. Secondary spread of disease is by contact of infected leaves with parts of 
adjoining healthy plants. The disease appears on plants at pre-flowering stage (40 to 50 day old plant) and within a period of 15 to 20 days, spreads under favourable conditions from the lower most sheath to the ear shoot. The infection continues to mid-dough stage covering the entire plant including the ear but not the tassel. Seeds are not considered to be a source of inoculum and may not play a major role in severe disease outbreaks. If ear infection occurs at the late stage, germination of the seed is adversely affected resulting in seed rot and seedling blight. The pathogen produces distinct horse-shoe shaped lesions on seed, the seed inoculum is of little importance in areas where the disease is already known to occur since the pathogen is soil borne and also grows on a large number of cultivated and wild plants.

\section{Environmental conditions}

Banded leaf and sheath blight is a potential threat to maize cultivation under conditions of high humidity and high temperature. High relative humidity and rain fall significantly favors development and spread of this disease. A range of temperature from 25 to $30^{\circ} \mathrm{C}$ coupled with an average relative humidity of $90-100 \%$ is most suitable for development of BLSB disease in maize (Singh and Sahi, 2012). Similarly, rainfall over $100 \mathrm{~mm}$ in the first 2 weeks favors severe infection and further disease development. If the relative humidity goes below $70 \%$, disease development and spread become very slow (Ahuja and Payak, 1981). Additionally, high crop densities at preflowering stage in 40-50 days old plants favor higher disease severity. The fungi spread by irrigation, movement of contaminated soil and infected plant debris. At the onset of growing season, in response to favourable humidity and temperature $\left(15\right.$ to $\left.35^{\circ} \mathrm{C}\right)$, the fungal growth is attracted to rapidly growing seedlings and water soaked seed coats by chemotropic stimulants released by growing plant cells and decomposing plant residue. Secondary spread of this disease occurs by contact of diseased leaves or sheath with healthy plants. High relative humidity $(90 \%)$, an optimum temperature about $28^{\circ} \mathrm{C}$, and rain fall in the first week of infection significantly favours the development and spread of disease. Disease development and spread becomes slow, if the relative humidity goes below 70\% (Sharma, 2005). Crop damage is caused by loss of photosynthetic leaf area due to foliar infection and stalk rot which lead to crop lodging (Lu et al., 2012). Sheath blight reduced the breaking resistance of lower internodes and consequently resulted in poor lodging resistance (Wu et al., 2012). The maximum damage is caused when ears of maize are infected (Ahuja and Payak, 1982).

\section{Management of banded leaf and sheath blight}

Banded leaf and sheath blight disease is very destructive in nature and difficult to control either host resistance, cultural, biological and chemical. Several workers have reported some resistance source against BLSB. Buddemeyer, et al., (2004) screened 55 maize genotype or breeding lines for resistance to $R$. solani. Li et al., (2009) observed the two inbred lines R15 and Ye 478 were grown in field plots in 2007 in Ya'an, Sichuan, China, to investigate the functional effects of different defense enzymes on the banded leaf and sheath blight (BLSB) caused by Rhizoctonia solani of maize. Madhavi et al., (2012) studied in sixteen maize genotypes including five popular varieties and twelve inbred lines at Maize research centre. Out of 12 inbred lines, BH11 showed moderate resistance to the disease. Chen et al., (2013) identified 282 maize inbred lines as resistance to BLSB. The results showed that no immune and highly resistant germplasm was found and four moderately resistant inbred lines 
were identified. Izhar and Chakraborty (2013) studied on Line $\times$ tester analysis involving 12 inbred lines and 5 inbred testers to evaluate the genetics of resistance against banded leaf and sheath blight in maize incited by Rhizoctonia solani. Out of seventeen inbreds including five testers, three lines were resistant, twelve lines were moderately resistant and two lines were moderately susceptible.

Cultural practices have been effective against management and minimizing the losses caused BLSB in maize. Sharma and Hembram (1990) reported that proper plant population and application of cattle compost (FYM) prior to planting, helped in decrease of disease level and its subsequent spread in field. Inter-cropping system of maize with legumes especially with soybean effectively reduced the disease severity and population of the pathogen in soil (Kato and Incue, 1995). Mehra et al., (2012) reported that stripping of the second and third leaf sheaths from the ground level at the age of 35-40 days old maize crop, reduced the disease severity and checked the spread of disease. Selection of a well-drained field and planting on raised beds are important cultural aspects to avoid contact of excess water with seeds and faster growth of seedlings (Hooda et al., 2015).

\section{Biological control}

Disease management through biological agents and botanical extracts is also of great importance. Several micro-organisms viz., Trichoderma, Gliocladium, Pseudomonas, Bacillus subtilis have been reported to parasitize Rhizoctonia species. The use of these microorganisms not only reduces disease incidences it also improves plant growth. Muis and Quimio (2006) developed a formulation of Bacillus subtilis and tested as seed treatment against $R$. solani. This $B$. subtilis BR23 formulation supressed $R$. solani in microplots and increased grain yield by $27 \%$ compared to that of the control captan with 14.4 per cent. Madhavi et al., (2011) tested Pseudomonas flurorescens aganist $R$. solani in-vitro condition and inhibition of mycelial growth and sclerotial germination of $R$. solani was ranging from $48 \%-92 \%$ and $29 \%-87 \%$ respectively over check. Trichoderma sp. found to be an effective biocontol agent, provided as high as $68 \%$ of inhibition of the mycelia of $R$. solani, under in vitro conditions, compared to the control of BLSB (Sharma et al., 2002). Meena et al., (2003b) reported that Trichoderma releases volatile compound and suppress both growth and sclerotial formation of $R$. solani. Trichoderma harzianum inhibited growth (80\%) and sclerotium formation (34\%) followed by $T$. viride which inhibited $70 \%$ growth and 26\% sclerotial formation. Trichoderma hyphae coiled around $R$. solani hyphae and subsequently caused the cell wall lysis (Yobo et al., 2004). Sahar et al., (2009) found highest reduction in the growth of $R$. solani by $T$. hamatum.

Rani et al., (2013), examined fungicides and biocontrol agents viz. benomyl, carbendazim, thiram, $T$. viride, $P$. fluorescens and $B$. subtilis as seed and soil treatments against BLSB. Among all the treatments carbendazim and $T$. viride showed $37.93 \%$ and $41.9 \%$ nrespectively, reduction in BLSB disease severity. Rajput (2013) reported Trichoderma harzianum effective against BLSB in vitro and in field studies, seed treatment with Pseudomonas fluorescens@10g kg-1 seed followed by two sprays of Propiconazole 25 EC @ $0.1 \%$ at 30 and 40 DAS was found most effective treatment and resulted in lowest PDI (20.40\%). This treatment increased grain yield $(40.72 \%)$ and fodder yield $(44.68 \%)$ over untreated check. Tagele et al., (2018) first reported effectiveness of multi-trait Burkholderia contaminans KNU17BI1 in growth promotion and 
management of banded leaf and sheath blight in maize seedling.

Many attempts have been made to control BLSB of maize through fungicides under in vitro and field condition. Different fungicides viz. Carbendazim, Benodanil, Thiobendazole, Validamycin, Topsin M, Rhizolex, Propiconazole etc. have been tested and found to be effective in inhibiting growth of the BLSB pathogen under in vitro condition. Earlier, several fungicides like use of carbendazim, benodanil and validamycin have been found effective against $R$. solani (Ahuja and Payak, 1986; Sharma and Rai, 1999). Batsa et al., (2004) reported maximum return (Rs 5.88) from each rupee investment when BLSB infected maize crop was sprayed with validamycin. Saxena (2002) reported that propiconazole is the best fungicide compared to carbendazim. Akhtar et al., (2010), recommended that management of BLSB can be achieved by integrating soil application of T. harzianum precolonized farmyard manure (FYM) with foliar application of carbendazim. Singh (2011) found best performance of Validamycin $(0.25 \%)$ and $T$. viride as foliar spray than the fungicides like Tilt $(0.15 \%)$ and Bavistin $(0.1 \%)$ and bioagent $P$. florescence which contributed higher maize grain yield over check. Seed dressing fungicides i.e. Bavistin 50WP, Vitavax Power $35.5 \%$ + Thiram $37.5 \%$, and Thiram 50 WP were tested against BLSB and Bavistin fungicide was found highly effective with $48.7 \%$ disease control and highest maize yield of $64.7 \mathrm{q} / \mathrm{ha}$ over control (Rakesh et al.,2011). Carbendazim, neem oil and $T$. harzianum as seed treatment (ST) and combinations of sprays with ST were found effective for managing BLSB of maize in field condition (Bunker et al., 2012). Malik et al., (2018) recently reported that most effective in reducing the percent disease index and produced superior yield by validamycin $0.3 \% \mathrm{~L}$ at $0.1 \%$ and trifloxystrobin $25 \%+$ tebuconazole $50 \%$ at $0.05 \%$ in field conditions. Chaudhary et al., (2016) stated the integrated management approaches evolved particularly in the present changing climate would provide sustainable management of BLSB.

\section{Is BLSB a potential threat to maize cultivation in Bihar?}

The fungus Rhizoctonia solani is a major pathogen of maize worldwide, particularly in China, South Asian and South East Asian countries. It causes banded leaf and sheath blight (BLSB) on plants, which is considered an emerging disease, accompanied by small losses to total wipeout of the crop. This disease is more prevalent in humid weather with temperature around $28^{\circ} \mathrm{C}$. Climate change is a threat of the present maize cultivation in Bihar. Changes in temperature and precipitation regimes due to climate change may alter the growth stage, development rate and pathogenicity of infectious agents, and the physiology and resistance of the host plant. In India, in the last decade the disease scenario of chickpea and pigeon pea has changed drastically; dry root rot (Rhizoctonia bataticola) of chickpea and Phytophthora blight (Phytophthora drechsleri f. sp. cajani) of pigeon pea have emerged as a potential threat to the production of these pulses. Maize crop is infected by approximately 65 pathogens which include fungi, bacteria and viruses (Rahul and Singh, 2002). Among the various diseases of maize, banded leaf and sheath blight has attained the status of economically important disease and potential threat to maize cultivation under conditions of high humidity and high temperature (Rajput and Harpur, 2014). It is now becoming minor to major disease of maize in Bihar because incidence and severity of BLSB is day by day increasing and causing severe losses in some districts. For a disease to occur a virulent pathogen, susceptible host 
and favourable environment are essential. All of these components are strongly coupled with environmental conditions. Global climate changes have the potential to modify host physiology and resistance, and alter both stages and rates of pathogen development. Environmental conditions controlling disease development include rainfall, relative humidity, temperature and sunlight. Changes in these factors under climate change are highly likely to have an effect on the prevalence of diseases and emergence of new diseases.

The disease infection cycle includes inoculum survival, infection, latency period, production of new propagules and dispersal, all of which are strongly influenced by environmental conditions. The penetration or infection of a plant by infectious propagules is determined by specific environmental conditions. In general, fungi require high relative humidity or moist leaf surfaces for infection; changes in these conditions will increase infection rates. For example, Cercospora zeae-maydis and Cercosporazeina cause gray leaf spot in maize and are highly sensitive to environmental conditions (Crous et al., 2006). Under dry conditions (relative humidity < $80 \%$ ), the pathogen ceases to grow and infection stops (Thorson and Martinson, 1993). Therefore, changes in temperature, humidity and rainfall patterns have the potential to increase infection by many maize pathogens. Increased temperature reduces the latency period (generation time) resulting in a higher number of generations per season. Generation time determines the amplification of plant disease in two ways accelerating and increasing inoculums potentially allowing the pathogen to adapt faster to the environment than the host.

Climate change may also affect gene flow, the process through which particular alleles or individuals are exchanged among separate populations. This will increase pathogen population diversity leading to variation in host resistance, variation in pathogen virulence and new specific interactions. This has the potential to result in new diseases or pathogen emergence, and the introduction of pathogens into new ecological niches. Depending on the distribution of populations and environmental conditions that are influenced by climate change, gene flow leads to an increase in population diversity or to the introduction of a new population in new ecological niches.

For example the, $F$. graminearum, is predominate in temperate maize growing environments, whereas $F$. verticillioides and $F$. proliferatum and fumonisins are more widely spread in tropical and subtropical environments (Miller, 1994). The optimal temperature range for $F$. graminearum is between $24-28{ }^{\circ} \mathrm{C}$ and above this temperature range $F$. verticillioides out competes $F$. graminearum (Miller, 2001; Reid et al., 1999). Increasing temperatures within maize growing regions are highly likely to change the geographical distribution and predominance of $F$. verticillioides, particularly in currently cooler regions where it will replace $F$. graminerum. Increased incidence of $F$. verticillioides and subsequent fumonisin contamination has already been reported in Guatemala, Mexico, Zimbabwe and Kenya (Torres et al., 2007).

Climate change is predicted to have a direct impact on the occurrence and severity of diseases in crops, which will have a serious impact on our food security. Climate change will result in rise in temperature and carbon dioxide levels and will also have a varied effect on moisture. In many cases, temperature increases are predicted to lead to the geographic expansion of pathogen and vector distributions, bringing pathogens into contact with more potential hosts and 
providing new opportunities for pathogen hybridization. In Bihar, under climate changing scenario such as favourable environment for pathogen, maize crop season after season, year after year, commercial hybrids and non-adoption of proper disease management practices by the farmers, Banded leaf and sheath blight could be potential threat to maize cultivation in Bihar.

\section{References}

Ahuja, S.C., and Payak, M. M 1982. Symptoms and signs of banded leaf and sheath blight in maize. Phytoparasitica. 10:41-49.

Ahuja, S.C., and Payak, M. M. 1986. In vitro response of maize and rice isolates of Rhizoctonia solani to antibiotic and fungi-toxicants. International Rice Research Newsletter. 11: 16.

Ahuja, S.C., and Payak, M.M. 1981. A laboratory method for evaluating maize germplasm to banded leaf and sheath blight. Indian Phytopathology. 31:34 37.

Akhtar, J., Kumar, V., Tiu, K.R., and Lal, H.C. 2010. Integrated management of banded leaf and sheath blight disease of maize. Plant Disease Research. 25 (1): 35-38.

All India Coordinated Maize Improvement Project (AICMIP). 1996. Maize at Pantnagar. Annual Progress Report: Maize Pathology. AICMIP. 15.

Batsa, B. K., Sharma, R. C., and Rai, S. N. 2004. Comparative efficacy of cultural, chemical and biological control against banded leaf and sheath blight in maize. In: Proceedings of the 24th national summer crops research workshop on maize research and production in Nepal, June 28-30, 2004, Kathmandu, Nepal, Pp. 232.

Bertus, L., 1927. A sclerotial disease of maize due to Rhizoctonia solani. Year book.
Department of Agriculture, Ceylon. pp 46-485.

Buddemeyer, J., Pfahler, B., Peterson, J., and Marlander, B. 2004. Genetic variation in susceptibility of maize to Rhizoctonia solani (AG2-2IIIB)-symptoms and damage under field conditions in Germany. Journal Plant Disease Protection. 111:521-53318.

Bunker, R.N., Trivedi, A., and Mathur, K. 2012. Integrated management of banded leaf and sheath blight of maize caused by Rhizoctonia solani f. sp. sasakii. Journal of Mycology and Plant Pathology. 42:367-371.

Chaudhary, S., Sagar, S., Tomar, A, Sengar, R.S., and Kumar, M. 2016. Banded leaf and sheath blight: A menacing disease of maize (Zea mays L.) and its management. Journal of Applied and Natural Science. 8 (3): 1720 - 1730.

Chen, K.C., Ravichandran, A., Guerrero, A., Deng, P., Baird, S.M., Smith, L., and Lu, S.E. 2013. The Burkholderia contaminans MS14 ocfC gene encodes a xylosyltransferase for production of the antifungal occidiofungin. Applied Environment Microbiology. 79 (9): 2899-2905.

Crous, P. W., Groenewald, J. Z., Groenewald, M., Caldwell, P. Braun, U. and Harrington, T. C. 2006. Species of Cerceospora associated with grey leaf spot of maize. Studies in Mycology. 55: 189-197.

De Candolle, A.P. 1915. Memorie surles rhizoctones, nouveaugenre de chamignons qui attaque lesrecines, des planets et enparticulier celle de la luzerne cultivee. Mem Mus Nat Hist NatSer. 2:209-216.

Directorate of Economics and Statistics. 2014. Agricultural Statistics at a Glance 2014, Department of Agriculture and Cooperation, Ministry of Agriculture, Government of India, New Delhi. 
Duggar, B.M. 1915. Rhizoctonia crocorum (Pres.) D.C. and R. solani Kuhn (Corticium vagum $\mathrm{B}$ and $\mathrm{C}$ ) with notes on other spices. Annals of the Missouri Botanical Garden, 2: 403-458.

Gautam, H.R., Bhardwaj and Kumar, R. 2013. Climate change and its impact on plant diseases. Current Science. (105) 12: 1685-1691.

Groth, D.E., and Bond, J.A. 2006. Initiation of rice sheath blight epidemics and effect of application timing of azoxystrobin on disease incidence, severity, yield, and milling quality. Plant Disease. 90 (8), 1073-1076.

Hooda, K.S., Khokhar, K.M., Parmar, H., Gogoi, R., Joshi, D., Sharma, S.S., and Yadav, O.P. 2017. Banded leaf and sheath blight of maize: historical perspectives, current status and future directions. Proc. Natl. Acad. Sci., India, Sect B Biological Science. 87 (4): 1041-1052.

Hooda, K.S., Khokhar, M.K., Parmar, H., Gogoi, R., Joshi, D., Sharma, S.S., and Yadav, O.P. 2015. Banded Leaf and Sheath Blight of Maize: Historical Perspectives, Current Status and Future Direction. Proc. Natl. Acad. Sci., India, Sect. B Biological Science, 1-12.

https://www.thehindubusinessline.com/econo my/agri-business/need

India Infoline News Service, 20 November, 2017 11:59 IST

Izhar, T., and Chakraborty, M. 2013. Genetic analysis of banded leaf and sheath blight resistance (Rhizoctonia solani) in maize. Journal of Pharmacognosy and Phytochemistry. 1: 1-5.

Kato, A. and Incue, Y. 1995. Resistance to banded leaf and sheath blight (Rhizoctonia solani Kühn) after fall of lower sheaths in maize (Zea mays L). Bulletin of the National Grass/and Research Institute (Japan), 51: 1-5.
Lal, S., Baruah, P. and Butchaiah, K. 1980. Assessment of yield losses in maize cultivars due to banded leaf sclerotial disease. Indian Phytopathology. 29: 129-132.

Li, L., Yong, Y. M., ZhiMing, Z., PengFe, i L., GuangTang, P., MaoJun, Z. 2009. Functional effects of different defense enzymes on banded leaf and sheath blight of maize. Journal of Maize Sciences. 17(3): 99-102\&106.

Lin, H. J., Tan, D. F., Zhang, Z. M., Lan, H. Gao, S. B., Rong, T. Z., and Pan, G. T. 2008. Analysis of digenic epistatic and QTL $\mathrm{x}$ environment interactions for resistance to banded leaf and sheath blight in maize (Zea mays). International Journal of Agriculture and Biology. 10: 605-611.

Lu, Y.L., Xu, J., Yuan, Z.M., Hao, Z.F. Xie, C.X., Li, X.H., Shah, T., Lan, H., Zhang, S.H., Rong, T.Z. and Xu, Y.B. 2012. Cooperative LD mapping using single SNPs and haplotypes identifies QTL for plant height and biomass as secondary traits of drought tolerance in maize. Molecular Breeding. 30: 407418.

Madhavi, G.B., Bhattiprolu, S.L., Bharathi, S., Reddy, V.C. and Ankaiah, R. 2011. Studies on the management of banded leaf and sheath blight disease of maize (Rhizoctoniz solani f. sp. sasakii) using fluorescent Pseudomonads. In: Proc. 2nd Asian PGPR Conference, Beijing P.R. China, pp 567-576.

Madhavi, G.B., Devi, G.U., Kumar, K.V.K. Babu T.R., and Naidu, T.C.M. 2018. Evaluation of Pseudomonas fluorescens and Trichoderma harzianum isolates in inducing systemic resistance (ISR) in maize against Rhizoctonia solani $\mathrm{f}$. Sp. Sasakii. International Journal of Chemical Studies. 6(2): 628-632.

Madhavi, M., Reddy, P. N., Reddy, R. R., and Sudarshan, M. R. 2012. Evaluation of 
maize genotype against banded leaf and sheath blight disease incited by Rhizoctonia solani f. sp. sasakii (Kuhn) Exner. Journal Research of ANGRAU. 40(4): 20-23.

Maiti, S., 1978. Two ear rots of maize from India. Plant Disease Reporter. 62: 10741076.

Malik, V.K., Singh, M., Hooda, K.M., Yadav, N.K., and Chauhan. P.K. 2018. Efficacy of newer molecules, bioagents and botanicals against maydis leaf blight and banded Leaf and sheath blight of maize. Plant Pathology. 34(2): 121-125.

Meena, R., Rathore, L. and Kusum Mathur, R.S. 2003b. Efficacy of biocontrol agents against Rhizoctonia solani $\mathrm{f}$. sp. sasakii causing banded leaf and sheath blight of maize. Journal of Mycology and Plant Pathology. 33(2): 310-312.

Meena, R., Rathore, L., and Kusum Mathur, R.S. 2003. Efficacy of biocontrol agents against Rhizoctonia solani f. sp. sasakii causing banded leaf and sheath blight of maize. Journal of Mycology and Plant Pathology. 33 (2), 310-312.

Mehra, R., Kamboj, M.C., Mehla, J.C., Madan, L., and Chand, M. 2012. Status of maize diseases and their management in Haryana. In: Proceedings of national seminar on sustainable agriculture and food security: challenges in changing climate. CCS HAU, Hisar, 27-28 Mar 2012. pp 217.

Miller, J. D., 2001. Factors that affect the occurrence of fumonisin. Environment Health Perspective. 109: 321-324.

Miller, J.D. 1994. Epidemiology of Fusarium graminierum disease of wheat and corn. In: Mycotoxins in grain: compounds other than Aflatoxin (J.D. Miller and H.L. Trenholm HL, Eds.), Eagan Press. pp 19-6.

Muis, A., and Quimio, A.J. 2006. Biological control of banded leaf and sheath blight disease (Rhizoctonia solani Kühn) in corn with formulated Bacillus subtilis BR23. Indonesian Journal of Agricultural Science. 7(1): 1-7.

Ogoshi, A., 1975. Grouping of Rhizoctonia solani Kühnand their perfect stages. Review on Plant Protection Research. 8: 93-103.

Parihar, C.M., Jat, S. L., Singh, A.K. Sai Kumar, R., Hooda, K.S., Chikkappa, G.K. and Singh, D.K. 2011. Maize Production Technologies in India. DMR Technical Bulletin 2011/ Directorate of Maize Research, Pusa Campus, New Delhi-110 012. pp 30.

Payak, M. M., and Sharma, R. C. 1981, Disease and pest situation in high yielding hybrids and composites of maize with special reference to India. A review of pest, diseases and weed complexes in high yielding varieties in Asia and Pacific. F. A. O. Regional office, Bangkok, Thailand. pp. 84-89.

Payak, M.M., and Renfro, B.L. 1966. Diseases of maize new to India. Indian Phytopathological Society Bulletin. 3:14-187.

Rahul, K., and Singh, I.S., 2002. Inheritance of resistance to banded leaf and sheath blight (Rhizoctonia solani f. sp. sasakii) of maize. In: Proc. 8th Asian Regional Maize Works. Bangkok, Thailand, vol. 5. pp. 356-365.

Rajpoot, L.S., 2013. Studies on Banded leaf and sheath blight of maize caused by Rhizoctonia solani f. sp. sasakii Exnerr M.Sc (Ag.) Thesis. DOI: 10.13140/RG.2.2.23087.74401.

Rajput, L.S., and Harpur S.I. 2014. Status of banded leaf and sheath blight of maize in North Karnataka. Karnataka. Journal of Agricultural Sciences. 27 (1): (8284).

Rakesh, D., Guleria, S.K., and Thakur, D.R. 2011. Evaluation of seed dressing fungicides for the management of 
banded leaf \& sheath blight of maize. Plant Disease Research. 26 (2): 169.

Rani, V.D., Reddy, P.N. and Devi, G.U. 2013. Banded leaf and sheath blight of maize incited by Rhizoctonia solani f. sp. sasakii and its management- A review. International Journal of Applied Biology and Pharmaceutical Technology. 4: 52-6.

Rani, V.D., Reddy, P.N., and Devi, G.V. 2015. Banded leaf and sheath blight of Maize incited by $R$. solani f. sp. sasakii. International Journal of Applied Biology and Pharmaceutical Technology, (4) 4: 51-60.

Reid, L. M., Nicol, R. W., Ouellet, T., Savard, M., Miller, J. D., Young, J. C., Stewart, D. W., and Schaafsma, A. W. 1999. Interaction of Fusarium graminearum and $F$. moniliforme in maize ears: Disease progress, fungal biomass, and mycotoxin accumulation. Phytopathology. 89:1028-1037.

Reyes, G.M., 1941. Notes on diseases affecting maize in Philippines. Journal of Agriculture. 12: 61-69.

Sahar, A., El-Sayed, Rania, Z., El-Shennawy and Tolba, A.F. 2009. Efficacy of chemical and biological treatments for controlling soil borne pathogens of soybean. Journal of Agricultural Science. 17(1): 163-173.

Saxena, S.C., 2002. Bio-intensive integrated disease management of banded leaf and sheath blight of maize. In: Proceed of $8^{\text {th }}$ Asian regional maize workshop: new technologies for the New Millennium, Bangkok, Thailand, pp. 380-388

Sharma, R. R., Gour, H. N., and Rathode, R. S. 2004, Etiology of banded leaf and sheath blight symptoms of maize. Journal of Mycology and Plant Pathology. 34 (1): 57-59.

Sharma, R.C., 2005. Banded leaf and sheath blight (Rhizoctonia solani f. sp. sasakii) of maize. In: Stresses of maize in
Tropics. (Zaidi PH, Singh NN eds). Pp. 159-171

Sharma, R.C., and Hembram, D. 1990. Leaf stripping: a method to control banded leaf and sheath blight of maize. Current Science. 59:745-746.

Sharma, R.C., and Rai, S.N. 1999. Chemical control of banded leaf and sheath blight of maize. Indian Phytopathology. 52 (1): 94-95.

Sharma, R.C., Srinivas, P., and Batsa, B.K. 2002a. Banded leaf and sheath blight of maize its epidemiology and management. In: Rajbhandari NP, Ransom JK, Adhikari K, Palmer AFE (eds) Proceedings of a maize symposium held. NARC and CIMMYT, Kathmandu, 3-5 Dec 20016. pp 108112.

Sharma, R.R., 1999. Pathological and biological attribute of Rhizoctonia solani f. sp. sasakii Exner, the causal organism of banded leaf and sheath blight of maize. M. Sc. Thesis, RAU, RCA, Udaipur.

Singh, A., and Shahi, J.P. 2012. Banded leaf and sheath blight: an emerging disease of maize. Maydica 57:215-219.

Singh, A., and Singh, D. 2011. Integrated disease management strategy of banded leaf and sheath blight of maize. Plant Disease Research. 26:192.

Singh, B.M and Sharma, Y.R. 1976. Evaluation of maize germplasm to banded sclerotial disease and assessment of yield loss. Indian Phytopathology. 29: 129-132.

Sohi, H.S., Sharma, S.L., and Verma, B.R. 1965. Diseases of maize occurring in HP. Proceeding of Maize Improvement Conference, New Delhi, pp: 122-124.

Sumner, D.R., and Minton, N.A. 1989. Crop losses in corn induced by Rhizoctonia solani AG2-2 and nematodes. Phytopathology. 79:934-941. 
Tagele, S.B., Kim, S.W., Lee, H.G., Hyun Seung Kim, H.S. and Youn Su Lee, Y.S. 2018. Effectiveness of multi-trait Burkholderia contaminans KNU17BI in growth promotion and management of banded leaf and sheath blight in maize seedling. Microbiological Research. 214: 8-18.

Thakur, S.M., Sharma, S.L., Munjal, R.L. 1973. Correlation studies between incidence of banded sclerotial disease and ear yield in maize. Indian Journal Mycology Plant Pathology. 3:180-181.

Torres, O. A., Palencia, E., Lopez de Pratdesaba, L., Grajeda, R., Fuentes, M., Speer, M. C., Merrill Jr, A. W., Glenn, A. E., and Riley, R. T. 2007.
Estimated fumonisin exposure in Guatemala is greatest in consumers of lowland maize. Journal of Nutrition. 137: 2723-2729.

Wu, W., Huang, J., Cui, K., Nie, L., Wang, Q., Yang, F., Shah, F., Yao, F. and Peng, S. 2012. Sheath blight reduces stem breaking resistance and increases lodging susceptibility of rice plants. Field Crops Research. 128: 101-108.

Yobo, K.S., Laing, M.D., Hunter, C.H., and Morris, M.J. 2004. Biological control of Rhizoctonia solani by two Trichoderma species isolated from South African composted soil. South African Journal of Plant and Soil.88: 265-268.

\section{How to cite this article:}

Dinesh Rai and Singh, S.K. 2018. Is Banded Leaf and Sheath Blight a Potential Threat to Maize Cultivation in Bihar? Int.J.Curr.Microbiol.App.Sci. 7(11): 671-683.

doi: https://doi.org/10.20546/ijcmas.2018.711.080 